Article

\title{
Consumers' Social Representations of Meat Safety in Two Selected Restaurants of Raymond Mhlaba Municipality in the Eastern Cape, South Africa
}

\author{
Lumka S. Dastile $^{1, *}$, Joseph Francis ${ }^{2}$ (D) and Voster Muchenje ${ }^{1}$ \\ 1 Department of Livestock and Pasture Science, University of Fort Hare, P. Bag X1314, Alice 5700, \\ Eastern Cape, South Africa; vmuchenje@ufh.ac.za \\ 2 Institute for Rural Development, University of Venda, Private Bag X5050, Thohoyandou 0950, Limpopo, \\ South Africa; joseph.francis@univen.ac.za \\ * Correspondence: lumka.dastile@gmail.com; Tel.: +27-40-602-2059; Fax: +27-86-409-8816
}

Received: 22 July 2017; Accepted: 14 September 2017; Published: 26 September 2017

\begin{abstract}
This study was conducted at two different restaurants of Raymond Mhlaba Municipality (Alice), Eastern Cape, South Africa, to determine consumers' social representations of meat safety. A total number of 251 people were interviewed in focus group discussions, each comprising 4-6 interviewees were conducted. Each focus group consisted of university students and staff, and members of rural communities surrounding the town of Alice. A semi-structured questionnaire comprising both closed-ended and open-ended questions was used to collect data. Consumers were concerned about the hygiene at the place of purchase and the freshness of meat. Moreover, they revealed that they were always worried about the risk of food-borne diseases. Although food-borne diseases were not cited as a significant problem, related ideas such as "washing of hands before preparation of food to minimize food-borne diseases" were important to consumers. Consumers indicated that meat safety at the abattoirs should be thoroughly managed given that "hygiene during meat processing is important to prevent the occurrence of food-borne diseases". Consumers in both retail outlets have shown to have a limited understanding of meat safety. Thus, consumers' social representations, perceptions, and knowledge are complex and dynamic with respect to meat safety.
\end{abstract}

Keywords: consumers' knowledge; food-borne diseases; meat supply chain; microbial contamination

\section{Introduction}

Social representations (SRs) refer to information arranged in a systematic way with different consumer attitudes, opinions, and beliefs about a given product [1]. In urbanized societies, socio-cultural and integration procedures constitutes SRs. People's backgrounds and authenticity influence SRs [2]. Social representations can be substituted or integrated into an individual's behavior, awareness, and social critical thinking. Currently, consumers face challenges with respect to how to judge risks regarding meat safety. Their insights on meat safety are based on the trust placed in the meat supply chain, which does not persist over time [3]. All these issues are crucial and must receive attention when formulating regulations and programs concerning meat safety.

Debates on regulations and implementing strategies that reassure consumers about meat safety have persisted for many years [4-6]. At the same time, increased awareness of the threat of Salmonella and Escherichia coli has decreased consumers' self-confidence in the quality and safety of their meat [7]. Thus, effective safety management systems remain a major concern for meat producers, processors, and consumers [8]. Verbeke et al. [9] conducted a study that revealed that consumers were expecting all types of foods including meat to be intrinsically safe. This observation explained why consumers never intentionally purchased or consumed unsafe food. This surely explains why the authors of [10] 
argue that consumers' knowledge of meat safety is insufficient and should be addressed. Incidences involving microbiological contamination have been triggered, and sustained efforts have been made to create awareness of meat-safety-related risks [11]. Microbial, especially bacterial contamination results in food-borne diseases linked to consumers' health risks namely diarrhea, vomiting, and fever $[6,12]$. Food-borne diseases negate human health and wellbeing, as well as productivity $[13,14]$. Regardless of the high incidences of food-borne illnesses in both developed and underdeveloped countries, there is still inadequate information required to amount effective interventions that addresses the problem. Therefore, it is not surprising that an awareness of bacteria that cause food-related illnesses in these areas remains low $[10,15]$.

Research conducted to date on meat safety risks has predominantly been biased towards quantifiable aspects such as consumer's perspective scales or psychological tests involving normal or large samples of individuals [16,17]. Qualitative techniques have been used to ascertain consumers' ideas, knowledge, beliefs, values, feelings, and preferences behind their behavior and their social group's symbolic construction of meanings [18-22]. Yet the use of qualitative methods simplifies focus groups' perspectives mainly by offering flexibility and innovation when applied [23]. Qualitative methods allow consumers to freely express their perceptions. In the current study, consumers' social representations and knowledge of meat safety in South Africa are explored. The objective was to compare consumers' social representations with respect to meat safety in two food settings.

\section{Materials and Methods}

\subsection{Study Site and Population}

The study was conducted at the University of Fort Hare Staff Centre and Champs restaurant in Alice of the Eastern Cape Province, South Africa. Alice is a small town with a population comprising various ethnic groups, nationalities, cultures, and religions. It is found in the Raymond Mhlaba local municipality of Amatole District. The Staff Centre is regarded as a top class outlet $\left(\mathrm{C}_{1}\right)$ and Champs Restaurant as a middle class outlet $\left(C_{2}\right)$. The former is a restaurant that is larger and has better equipment. Most university staff and students purchase food here during lunch time. It serves ready-to-eat breakfast and lunch, costing R18.00 and R30.00 (USD = ZAR 12.95), respectively. At the Staff Centre, a wide range of meats, such as pork, beef, mutton, fish, and chicken, are served. Most consumers residing in Alice purchase their meat at Champs restaurant. Chicken and chips are served starting at Combo 2 (two pieces of chicken with chips) at a price of R33.00. Combo 6 is the largest sold there.

\subsection{Data Collection and Participants}

Permission to interview staff, students, and consumers from rural communities was obtained from the University of Fort Hare Research Ethics Committee of the University of Fort Hare (UFH/UREC, MUC211SDAS01). A pre-testing survey was carried out prior to commencement of data collection. Postgraduate students who usually operate from the Animal Science Laboratory at the University of Fort Hare (UFH) participated in the pre-test. It was necessary to conduct the pre-test because it helped determine whether the questionnaire earmarked for use in data collection was effective and valid. The results of the pre-test were used to refine the questionnaire. Thereafter, 251 consumers from the Staff Centre $\left(C_{1}\right)$ and Champs $\left(C_{2}\right)$ restaurants were selected. In addition to this consideration, gender and ethnic groups were used as sub-clusters when sampling respondents. This made it possible to reduce potential bias during sampling. A semi-structured questionnaire comprising both closed-ended and open-ended questions was used to collect data during lunch times. Demographic data (Table 1) were collected in order to differentiate the focus groups. Focus group discussions were conducted and audio-taped. Prior to data collection, the participants were briefly informed about the purpose of the study. Consumers were afforded an opportunity to ask questions on issues that they did not 
understand well. Each sampled respondent who freely volunteered to participate in the study was requested to sign a written consent letter.

Table 1. Demographic information of consumers who participated in focus group discussion.

\begin{tabular}{|c|c|c|}
\hline Variable & Staff Centre & Champs \\
\hline \multicolumn{3}{|l|}{ Gender } \\
\hline Female & $110(58.51 \%)$ & $39(64.90 \%)$ \\
\hline Male & $78(41.49 \%)$ & $24(38.10 \%)$ \\
\hline \multicolumn{3}{|l|}{ Race } \\
\hline Black & $172(91.49 \%)$ & $56(88.89 \%)$ \\
\hline White & $7(3.72 \%)$ & $3(4.76 \%)$ \\
\hline Coloured & $9(4.79 \%)$ & $4(6.35 \%)$ \\
\hline \multicolumn{3}{|l|}{ Age, years } \\
\hline$<20$ & $31(16.49 \%)$ & $2(3.17 \%)$ \\
\hline $21-30$ & $102(56.26 \%)$ & $20(31.75 \%)$ \\
\hline $31-40$ & $38(20.21 \%)$ & $19(46.03 \%)$ \\
\hline $41-50$ & $14(7.45 \%)$ & $12(19.05 \%)$ \\
\hline$>50$ & $3(1.60)$ & 0 \\
\hline \multicolumn{3}{|l|}{ Employment } \\
\hline Employed & $55(29.26 \%)$ & $42(66.67 \%)$ \\
\hline Unemployed & $133(70.74 \%)$ & $21(33.33 \%)$ \\
\hline \multicolumn{3}{|l|}{ Educational status } \\
\hline No. formal education & 0 & $1(1.59 \%)$ \\
\hline Grade 1-7 & 0 & 0 \\
\hline Grade 8-12 & 0 & $2(3.17 \%)$ \\
\hline Tertiary & $100(100 \%)$ & 97 (95.24\%) \\
\hline \multicolumn{3}{|l|}{ Marital status } \\
\hline Single & $149(76.26 \%)$ & $38(60.32 \%)$ \\
\hline Married & $37(19.68 \%)$ & $24(38.10 \%)$ \\
\hline Widowed & $1(0.53 \%)$ & $1(1.59 \%)$ \\
\hline Divorced & $1(0.53 \%)$ & 0 \\
\hline
\end{tabular}

Each focus group was comprised of 4-6 participants, consisting of university students and staff, and residents of rural communities surrounding Alice. A total number of 88 staff members and 75 students were sampled at the Staff Centre and interviewed in 11 and 15 focus groups, respectively. At the Champs restaurant, 20 staff members or employed consumers were interviewed in 17 focus groups. Focus groups were constituted by selecting tables with 4-6 consumers in each restaurant. In-depth focus group discussions were carried out to obtain consumer understanding or opinion on the questions contained in the questionnaire. The questions that the focus groups deliberated on were as follows: (1) What do consumers regard as the meaning of meat safety? (2) What are food-borne diseases? Apart from this, the interviews focused on knowledge regarding primary meat production, processing, transportation, storage, distribution, preparation for consumption and extent of consumer involvement in the meat supply chain. For each question, probing to gain deeper insights entailed use of "tell me more about that" and "what else do you think about food safety?" Each focus group was given an opportunity to express its views freely. As the members narrated their views, a tape recorder was used to complement note taking.

\subsection{Statistical Analysis}

All the focus groups' responses were transcribed and rearranged per interview question. Their responses were recorded verbatim and grouped accordingly. Consumers' responses were sorted and placed per theme, linked to retail outlet, namely $C_{1}$ and $C_{2}$. The data were then coded and stored in MS Excel. The frequencies for consumers' profiles, knowledge, and perceptions were determined using 
the PROC FREQ procedure of the Statistical Analysis Systems (SAS, 2009). Mean perceived importance scores were also determined using the PROC MEAN procedure of SAS (2009). Statistical significance of responses was tested at the $95 \%$ confidence interval, with $(p<0.05)$ being regarded as significant.

\section{Results and Discussion}

Consumers' knowledge and ideas regarding meat safety are shown in Table 2. Hygiene and freshness of the meat were most important to consumers in both retail outlets $C_{1}(31.91 \%)$ and $\mathrm{C}_{2}(41.27 \%)$. It was revealed that consumers preferred to purchase meat from the higher class retail outlet, $C_{1}(19.68 \%)$ and believed that the meat sold at their outlet was safer compared to $C_{2}(26.98 \%)$. The fact that consumers think carefully about hygiene and safety prior to purchasing meat might explain this observation. Jabbar [24] reported similar results, stating that hygiene and freshness were the most considered factors that provided an indication of safety of meat at a purchase point. Moreover, Behrens et al. [25] and Vedovato et al. [26] compared two different food settings and observed that $\mathrm{R} 1$ was preferred as opposed to R2, mainly because the former was more hygienic. However, there is evidence [27-30] that suggests that consumers depend on only detectable cues associated with food hygiene when they evaluate meat safety. Thus, consumers' quality and safety assessments are essential for the production of high-quality, safe meat [31]. Therefore, these results show the basic perceptions and necessities of personal hygiene at a place of purchase, which plays a vital role in ensuring that products are safe for the consumer.

Table 2. Consumers' social representation regarding knowledge of the meaning of meat safety.

\begin{tabular}{lcccc}
\hline \multicolumn{1}{c}{ Perception? } & $\mathbf{C}_{\mathbf{1}} \mathbf{( \% )}$ & $\mathbf{C}_{\mathbf{2}} \mathbf{( \% )}$ & $\mathbf{C}_{\mathbf{1}}$ & $\mathrm{C}_{\mathbf{2}}$ \\
$\begin{array}{l}\text { "Meat safety involves hygiene and ensuring } \\
\text { that the meat is fresh until it reaches the retail } \\
\text { outlet/place of purchase" }\end{array}$ & 31.91 & 41.27 & $\begin{array}{c}\text { Place of purchase, } \\
\text { health, freshness }\end{array}$ & $\begin{array}{c}\text { Hygiene and } \\
\text { freshness }\end{array}$ \\
$\begin{array}{l}\text { "Meat safety means that we have to check the } \\
\text { information of the expiry date on a specific } \\
\text { cue/package" }\end{array}$ & 12.77 & 15.87 & $\begin{array}{c}\text { Sell by date, best } \\
\text { before, consuming } \\
\text { fresh meat }\end{array}$ & $\begin{array}{c}\text { Expiry date, sell by } \\
\text { date }\end{array}$ \\
$\begin{array}{l}\text { "Meat safety means that the meat is safe } \\
\text { for consumption" }\end{array}$ & 19.68 & 19.05 & Non-hazardous meat & Safety \\
$\begin{array}{l}\text { "Meat safety means that the meat is safe and } \\
\text { disease free" }\end{array}$ & 13.83 & 6.35 & $\begin{array}{c}\text { Sickness, food-borne } \\
\text { diseases }\end{array}$ & Healthiness \\
\hline $\begin{array}{l}\text { "It means that the quality of meat is } \\
\text { acceptable to consumers" }\end{array}$ & 5.85 & 6.35 & Colour, texture & $\begin{array}{c}\text { Sensory evaluation } \\
\text { (Quality) }\end{array}$ \\
\hline $\begin{array}{l}\text { "The meat must be of good quality and } \\
\text { should contain nutrients that are needed. } \\
\text { It should also be free from diseases" }\end{array}$ & 10.11 & 11.11 & Disease free & $\begin{array}{l}\text { Quality and } \\
\text { non-disease }\end{array}$ \\
\hline $\begin{array}{l}\text { "I do not understand what meat safety is all } \\
\text { about. I just consume meat". }\end{array}$ & 5.85 & 3.17 & No clue & I do not know \\
\hline
\end{tabular}

$\mathrm{C}_{1}$-Staff Centre; $\mathrm{C}_{2}-$ Champs Restaurant.

In Table 2, the various ways in which consumers perceived the meaning of meat safety are shown. There was no clear pattern regarding how consumers at the two retail outlets regarded meat safety. However, most consumers who purchased meat at $C_{1}$ were students believed to be more educated and have more general knowledge regarding meat safety. Liana et al. [32] reported that well-educated consumers were often more up to date with issues concerning meat safety. Expiry dates shown on meat packages were more important measures of meat spoilage than visual appearance (meat colour). Educated consumers considered this, healthiness, and other variables during or after consumption [33]. Only a minority of consumers in both retail outlets did not understand the meaning of meat safety- "I do not understand what meat safety is all about, I just consume meat". 
As indicated in Table 3 , most consumers in both retail outlets $\left(C_{1}=40.43 \% ; C_{2}=50.79 \%\right)$ were of the view, and concerned, that microbial contamination contracted through food consumption caused diseases. Behrens et al. [34] and Behrens et al. [25] reported that food-borne diseases resulted from microbial contamination, which was a threat to their health and well-being. Some consumers indicated that they had limited control over their own exposure to microbial contaminants. Yet, microbial contaminants can cause food-borne illnesses with variable impacts on overall health and well-being [35]. Consumers' alertness showed that they understood the consequences of food-borne diseases, which supports Unusan's findings [36]. Although the proportions of consumers both $C_{1}(10.64 \%)$ and $\mathrm{C}_{2}(4.76 \%)$ were ignorant of food-borne diseases were, this should be regarded as a worrying situation that needs urgent attention.

Table 3. Perceived meaning of food-borne diseases.

\begin{tabular}{|c|c|c|c|c|}
\hline What Are Food-Borne Diseases? & $\mathrm{C}_{1}(\%)$ & $\mathrm{C}_{2}(\%)$ & $\mathrm{C}_{1}$ & $\mathrm{C}_{2}$ \\
\hline $\begin{array}{l}\text { "Are diseases that are contracted through } \\
\text { food consumption" }\end{array}$ & 40.43 & 50.79 & Meat contamination & $\begin{array}{c}\text { Microbial } \\
\text { contamination }\end{array}$ \\
\hline $\begin{array}{l}\text { "Are diseases that are occurring when } \\
\text { someone does not wash his/ her hands } \\
\text { during the preparation of meal" }\end{array}$ & 20.74 & 19.05 & $\begin{array}{l}\text { Food preparation, } \\
\text { proper hygiene }\end{array}$ & $\begin{array}{l}\text { Lack of personal } \\
\text { experience }\end{array}$ \\
\hline $\begin{array}{l}\text { "Are diseases that are causing us } \\
\text { stomachache, vomiting, nausea" }\end{array}$ & 13.30 & 17.46 & Sickness & Health purposes \\
\hline $\begin{array}{l}\text { Are disease like Salmonella, Escherichia coli, } \\
\text { Campylobacter and other bacteria's" }\end{array}$ & 11.17 & 7.94 & Food-borne diseases & Diseases \\
\hline $\begin{array}{l}\text { "Food-borne disease can be controlled } \\
\text { starting from the abattoir to the retail outlet. } \\
\text { At our homes we should be able to prepare } \\
\text { our meals in a hygienic place" }\end{array}$ & 3.72 & 7.94 & Washing of hands & Control \\
\hline $\begin{array}{l}\text { "I do not know what are the } \\
\text { food-borne disease" }\end{array}$ & 10.64 & 4.76 & Lack of understanding & I do not know \\
\hline
\end{tabular}

Even though consumers in $C_{1}$ were perceived as educated, their understanding of food-borne was not superior to those interviewed at $C_{2}$. Tokuc et al. [37] also found that consumers had poor knowledge of food-borne diseases. Interviewees were aware that the diseases could be minimized if they wash their hands when preparing food. There were consumers in both retail outlets who had basic knowledge on microbial contaminants such as Salmonella, Escherichia coli, and Campylobacter. Kher et al. [38] made similar observations, especially with respect to Salmonella and Escherichia coli. Although the respondents had a basic understanding of food-borne illnesses, they did not perceive food-borne diseases as a significant challenge. This perception might make consumers take meat safety issues for granted.

Consumers' responses with respect to the importance of knowledge about food-borne diseases are shown in Table 4 . Slightly more than a third (33.51\%) of consumers at $C_{1}$ and (44.44\%) $C_{2}$ had positive attitudes towards the need for introducing preventative measures for food-borne diseases from retail outlets. Zain and Naing [39] revealed that consumers understood that food-borne diseases could be prevented through better awareness and improved personal hygiene. Apart from prevention, hygiene, safety, and awareness were among the consumers' concerns. Hygiene and safety are broad issues that are significant in ensuring human health and safety [40]. The Codex Alimentarius Commision [41] of Rome reported that improper food handling was assumed to be a major cause of food-borne diseases, mainly resulting from poor hygiene practice. It is worth pointing out that having deep knowledge does not necessarily lead to changes in food handling behavior [42]. This implies that individuals play critical roles in eliminating the threat of food-borne diseases. 
Consumers' basic knowledge on the meat supply chain is indicated in Table 5. In both retail outlets ( $C_{1} 50.53 \%$ and $\left.C_{2} 55.56 \%\right)$, the most dominant view was that "safety from abattoir to retail outlet". The term "meat safety" should be viewed from a supply chain perspective that begins with production on the farm, slaughtering of the animal, primary production, and manufacturing and ends with storage and distribution, which includes retail [43]. It is crucial to manage the primary production chain up to the plate of a consumer in a manner that ensures food safety [44]. Consumers were not specific about their knowledge of the meat supply chain in the two retail outlets $C_{1}(23.40 \%)$ and $C_{2}(20.63 \%)$. However, some in $C_{1}(24.47 \%)$ and $C_{2}(17.46 \%)$ indicated that they were purchasing meat whose origin they did not know. This was a worrying observation because it reflected consumers' disinterest in making retailers uphold high-quality standards expected in such business enterprises. There were consumers in both retail outlets who indicated that stress could affect meat quality, suggesting that they did not have a clear understanding of the meaning of safety. In one study [45], consumers' knowledge of the supply chain as well as their concerns and acceptance of measures of meat safety were found to be different. Labuschagne et al. [46] revealed that the South African consumer market was diverse, comprising various cultures, races, preferences and market segments. The different behaviors and attitudes identified in the current study seemed to be a consequence of a perceptive conflict and a lack of understanding of the meat supply and production chains.

Table 4. Consumers' responses on the importance of knowing food-borne diseases.

\begin{tabular}{lccc}
\hline Why Is It Important to Know About Food-Borne Diseases? & $\mathbf{C}_{\mathbf{1}} \mathbf{( \% )}$ & $\mathbf{C}_{\mathbf{2}} \mathbf{( \% )}$ & Consumer Ideas \\
\hline "Be on the lookout of food-borne diseases so that we can be safe" & 33.51 & 44.44 & Prevent \\
"Hygiene is very important to reduce food-borne diseases" & 28.72 & 25.40 & Hygiene \\
"Safety measures are to be taken more especially to retail outlets and our homes" & 15.96 & 19.05 & Safety \\
"We should be aware the dangers that they cause in our lives" & 4.79 & 3.17 & Awareness \\
"I do not know" & 17.02 & 7.94 & I don't know \\
\hline
\end{tabular}

$\mathrm{C}_{1}$-Staff Centre; $\mathrm{C}_{2}-$ Champs Restaurant.

Table 5. Consumers' knowledge on the meat supply chain.

\begin{tabular}{lccc}
\hline \multicolumn{1}{c}{ Perception } & $\mathbf{C}_{\mathbf{1}} \mathbf{( \% )}$ & $\mathbf{C}_{\mathbf{2}} \mathbf{( \% )}$ & Consumer Ideas \\
\hline "This involves from farm to fork safety" & 50.53 & 55.56 & Safety from abattoir to retail outlet \\
"I am just purchasing meat without even knowing where it is from" & 24.47 & 17.46 & Just purchasing \\
"Stressing of animals from the abattoir can affect meat quality" & 1.60 & 6.35 & Meat quality \\
"I do not know" & 23.40 & 20.63 & No clue \\
\hline
\end{tabular}

$\mathrm{C}_{1}$-Staff Centre; $\mathrm{C}_{2}-$ Champs Restaurant.

Consumers' responses to other information importance regarding meat safety is presented in Table 6. Consumers in $\mathrm{C}_{1}(21.81 \%)$ and $\mathrm{C}_{2}(28.57 \%)$ indicated that "hygiene during meat processing" helped prevent incidences of food-borne diseases. Some consumers indicated that knowing the "origin and details of processing" $\left(C_{1}=19.86 \% ; C_{2}=26.98 \%\right)$ was crucial. Smaller proportions of the consumers $\left(C_{1}=10.36 \% ; 11.11 \%\right)$ were of the view that, "If the government can assist with education training to consumers," then meat safety would be enhanced. It is known that levels of hygiene in meat retail outlets differ due to transportation, handling, and processing and that microbial contamination levels are unlikely to be the same as well. Microbial contamination mostly occurs during the slaughter, processing, storage, and distribution at slaughterhouses and retail outlets [47]. This occurs because of the unhygienic handling of meat from slaughterhouses, butchering equipment, handling, transportation, and processing [48]. The results of the current study concur with the findings of [49], which highlighted that hygiene was important in food sector services. A study by Ruban and Fairoze [50] revealed that there were higher bacterial concentrations in meat as a result of how the latter was processed. Consumers solely rely on meat sectors and the preparation of food at a restaurant. This was aptly summed by one interviewee who said, "Finding yourself eating at a restaurant like Champs always gives you hope that the meat is hygienically free from contamination". The results of this study have 
indicated why high levels of hygiene should be attained. In addition, further research that assesses the general knowledge of workers and hygiene from abattoirs, retail outlets up to the plate of a consumer is required if high meat standards are to be achieved.

Table 6. Respondents' ideas on what else is important to share about meat safety.

\begin{tabular}{lccc}
\hline \multicolumn{1}{c}{ What Else Is Important to Share about Meat Safety? } & $\mathbf{C}_{\mathbf{1}} \mathbf{( \% )}$ & $\mathbf{C}_{\mathbf{2}} \mathbf{( \% )}$ & Consumer Ideas \\
\hline "Washing of hands before eating/ preparation of meat" & 11.70 & 14.29 & Sanitation \\
"Meat must be properly cooked at all times" & 7.98 & 4.76 & Meat preparation \\
"Meat colour should not change" & 14.36 & 7.94 & Meat colour \\
"Hygiene at the meat processing" & 21.81 & 28.57 & Hygiene \\
"Origin and details of processing" & 19.68 & 26.98 & Processing \\
"Food-borne illnesses" & 7.98 & 6.35 & Food-borne disease \\
"If the government can assist with education training to consumers" & 10.36 & 11.11 & Educational lessons \\
"I don't have anything to add" & 4.78 & 0 & I don't know \\
\hline
\end{tabular}

$\mathrm{C}_{1}$-Staff Centre; $\mathrm{C}_{2}$-Champs Restaurant.

\section{Conclusions}

It was revealed in this study that consumers relied on their visual assessment rather than their deep insights when they evaluated meat quality. The fact that consumers regarded hygiene as important indicates that meat processors, distributors, and food preparation workers should never compromise on it if they are to attract consumers. Consumers interviewed at both $C_{1}$ and $C_{2}$ had basic knowledge of the pathogenic diseases that causes meat to be unsafe for consumption, even though there were misconceptions, which could be addressed with awareness campaigns and the implementation of meat safety regulations.

Acknowledgments: The authors are grateful to the South African National Research Foundation Freestanding and Innovation bursary (SFH 14061369232), DST-NRF Centre of Excellence (Project number P801) and Govan Mbeki Research Development Centre for funding this study. Special gratitude goes to the managers of University of Fort Hare Staff Centre and Champs restaurant as well as the consumers who participated in the study.

Author Contributions: Lumka S. Dastile and Voster Muchenje conceptualized and designed the study. Lumka S. Dastile was accountable for conducting research, collecting data, and originating the draft manuscript. Joseph Francis and Voster Muchenje supervised the research and proofread the manuscript. The authors approved the content of this manuscript.

Conflicts of Interest: The authors declare no conflict of interest in relating to this study.

\section{References}

1. Lahlou, S.; Abric, J.-C. What are the "elements" of a representations? Pap. Soc. Represent. 2011, 20, 1-20.

2. Cárdenas, M.; Parra, L.; Picón, J.; Pineda, H.; Rojas, R. Las representaciones sociales de la Política y laDemocracia. Ultima Década 2014, 15, 53-78.

3. Five-Shaw, C.; Rowe, G. Public perceptions of every day food hazards: A psychometric study. Risk Anal. 1996, 16, 487-500. [CrossRef]

4. Jabbar, M.A.; Grace, D. Regulations for Safety of Animal Source Food in Selected Sub-Saharan African Countries: Current Status and Their Implications; The Safe Food, Fair Food Project International Livestock Research Institute: Nairobi, Kenya, 2012.

5. Govender, R.; Naidoo, D.; Buys, E.M. Managing meat safety at the South African abattoirs. Int. J. Biol. Biomol. Agric. Food Biotechnol. Eng. 2013, 4, 279-284.

6. Bhuvneswari, R.; Muthukumar, E. Food safety awareness among customers to avoid the risk of food-borne illness. J. Bus. Manag. Soc. Sci. Res. 2015, 4, 549-552.

7. De Jonge, L.; Frewer, L.; van Trijp, H.; Renes, R.J.; de Wit, W.; Timmers, J. The development of a monitor for consumer confidence in food safety: Results of an exploratory study. Br. Food J. 2004, 106, 837-849. [CrossRef] 
8. Shilenge, L.B. Microbial Hazards Associated with Meat Processing in Butcheries within Mangaung Metropolitan Municipal Area. Master's Thesis, Central University of Technology, Bloemfontein, South Africa, 2014.

9. Verbeke, W.; Lynn, J.F.; Scholderer, J.; Brabander, H.F. Why consumers behave as they do with respect to food safety and risk information. Anal. Chim. Acta 2007, 586, 2-7. [CrossRef] [PubMed]

10. Redmond, E.C.; Griffith, C.J. Consumer food handling in the home: A review of food safety studies. J. Food Protect. 2003, 66, 130-161. [CrossRef]

11. Ruth, M.W.; Yeung, J.M. Consumer perception of food risk in chicken meat. Nutr. Food Sci. 2001, 41, $270-279$.

12. Taege, A. Food-Borne Diseases. Available online: http://www.clevelandclinicmeded.com/medicalpubs/ diseasemanagement/infectious-disease/foodborne-disease/ (accessed on 9 October 2016).

13. Hoffman, S. A. U.S. Food Safety Policy Enters a New Era. Amber Waves: The Economics of Food, Farming, Natural Resources, and Rural America. Available online: http:/ / www.ers.usda.gov (accessed on 8 April 2016).

14. Newman, K.L.; Leon, J.S.; Rebolledo, P.A.; Scallan, E. The impact of socio-economic status on food-borne illness in high income countries: A systematic review. Epidemiol. Infect. 2015, 143, 2473-2485. [CrossRef] [PubMed]

15. United States Food and Drug Administration (USFDA). FDA/FSIS Food Safety Survey Topline Frequency Report. Available online: http:/ / www.fda.gov/Food/ScienceResearch (accessed on 6 April 2016).

16. Danelon, M.S.; Salay, E. Development of a scale to measure consumer perception of the risks involved in consuming raw vegetable salad in full-service restaurants. Appetite 2012, 59, 713-722. [CrossRef] [PubMed]

17. Uggioni, P.L.; Salay, E. Reliability and validity of a scale to measure consumer attitudes regarding the private food safety certification of restaurants. Appetite 2012, 58, 470-477. [CrossRef] [PubMed]

18. Fischer, A.R.H.; de Jonge, A.E.I.; de Jonge, R.; Frewer, L.J.; Nauta, M.J. Improving food safety in the domestic environment: The need for a transdisciplinary approach. Risk Anal. 2005, 25, 503-517. [CrossRef] [PubMed]

19. Hawkins, D.; Mothersbaugh, D.; Best, R. Consumer Behaviour: Building Marketing Strategy; McGraw Hill: Boston, MA, USA, 2007.

20. Lawless, H.T.; Heymann, H. Sensory Evaluation of Food-Principals and Practices; Aspen Publishers: Gaithersburg, PA, USA, 2010; p. 848.

21. Lefèvre, F.; Lefèvre, A.M.C. Depoimentos e Discursos-Uma Proposta de Análise Em Pesquisa Social [Testimonials and Speeches-A Proposal for Analysis in Social Research]; Liber Livro: Brasília, Brazil, 2012.

22. Favalli, S.; Skov, T.; Spence, C.; Byrne, D.V. Do you say it like you eat it? The sound symbolism of food names and its role in the multisensory product experience. Food Res. Int. 2013, 54, 760-771. [CrossRef]

23. Berkwits, M.; Inui, T.S. Making use of qualitative research techniques. J. Int. Med. 1998, 13, 195-199. [CrossRef]

24. Jabbar, M.A. Assessing Consumer Preferences for Quality and Safety Attributes of Food in the Absence of Official Standards: The Case of Beef in Ethiopia. In Proceedings of the International Association of Agricultural Economics Conference, Beijing, China, 16-22 August 2009.

25. Behrens, J.H.; Vedovato, G.M.; Cervato-Mancuso, A.N.; Bastos, D.H.M. Social representations of safety in food services. Food Res. Int. 2015, 74, 324-328. [CrossRef] [PubMed]

26. Vedovato, G.M.; Bastos, D.H.M.; Cervato-Mancuso, A.N.; Behrens, J.H. A scale to evaluate customer attitudes towards food risks in restaurants. Vig. Sanit. Debate 2014, 2, 53-61. [CrossRef]

27. Medeiros, L.C.; Hillers, V.N.; Chen, G.; Bergmann, V.; Kendall, P.; Schroeder, M. Design and development of food safety knowledge and attitude scales for consumer food safety education. J. Anim. Diet. Assoc. 2004, 104, 1671-1677. [CrossRef] [PubMed]

28. Redmond, E.C.; Griffith, C.J. Consumer perceptions of food safety risk, control and responsibility. Appetite 2004, 43, 309-313. [CrossRef] [PubMed]

29. Fatimah, U.Z.A.U.; Boo, H.C.; Sambasivan, M.; Salleh, R. Foodservice hygiene factors: The consumer perspective. Int. J. Hosp. Manag. 2011, 30, 38-45. [CrossRef]

30. Medeiros, C.O.; Salay, E. A review of food service selection factors important to the consumer. Food Public Health 2013, 3, 176-190.

31. Neme, A. Consumer Preference and Willingness to Pay for Sheep Meat Quality and Safety in Addis Ababa. Master's Thesis, Haramaya University, Dire Dawa, Ethiopia, 2011. 
32. Liana, M.; Radam, A.; Yacob, M.R. Consumer perception towards meat safety: Confirmatory factor analysis. IJEM 2010, 4, 305-318.

33. Grunert, K.G. What's in a steak? A cross-cultural study on the quality perception of beef. Food Qual. Preference 1997, 8, 157-174. [CrossRef]

34. Behrens, J.H.; Barcellos, M.N.; Frewer, L.J.; Nunes, T.P.; Franco, B.D.G.M.; Destro, M.T.; Landgraf, M. Consumer purchase habits and views on food safety: A Brazilian study. Food Control 2010, 21, 963-969. [CrossRef]

35. Lammerding, A.M.; Fazil, A. Hazard identification and exposure assessment for microbial food safety risk assessment. Int. J. Food Microbiol. 2000, 58, 147-157. [CrossRef]

36. Unusan, N. Consumer food safety knowledge and practices in the home in turkey. Food Control 2007, 18, 45-51. [CrossRef]

37. Tokuc, B.; Ekuklu, G.; Berberoğlu, U.; Bilge, E.; Dedeler, H.H. Knowledge, attitudes and self-reported practice of food service staff regarding food hygiene in Edrine Turkey. Food Control 2009, 20, 565-568. [CrossRef]

38. Kher, S.V.; de Jonge, J.; Wentholt, W.T.A.; Deliza, R.; de Andrade, J.C.; Cnassen, H.J.; Krystallis, A.; de Barcellos, M.D.; Kügler, J.O.; Verbeke, W.; et al. Attitudes of European citizens towards pig production systems. Livest. Sci. 2009, 126, 46-56.

39. Zain, M.M.; Naing, N.N. Social demographic characteristics of food handlers and their knowledge, attitude and practice towards food sanitation: A preliminary report. Southeast Asian J. Trop. Med. Public Health 2002, 33, 410-417. [PubMed]

40. Nel, S.; Lues, J.F.R.; Buys, E.M.; Venter, P. The personal and general hygiene practices in the deboning room of a high throughput red meat abattoir. Food Control 2004, 15, 571-578. [CrossRef]

41. Codex Alimentarius Commision. Recommended International Code of Practice General Principles of Food Hygiene; Codex Alimentarius Commision: Rome, Italy, 2003.

42. Ansari-Lari, M.; Soodbakhsh, S.; Lakzadeh, L. Knowledge, attitudes and practices of workers on food hygienic practices in meat processing plants in Fars, Iran. Food Control 2009, 21, 260-263. [CrossRef]

43. Stringer, M.F.; Hall, M.N.; The Breakdowns Food Safety Group. A Generic Model of the Integrated Food Supply Chain to Aid the Investigation of Food Safety Breakdowns. Food Control 2007, 18, 755-765. [CrossRef]

44. Food and Agriculture Organization (FAO). Recommended International Code of Practice General Principles of Food Hygiene. Available online: http:/ / www.fao.org/docrep/005/y1579e/y1579e02.htm (accessed on 31 July 2016).

45. Gellynck, X.; Verbeke, W. Consumer perception of traceability in the meat chain. Agrarwirtschaft 2001, 50, 368-373.

46. Labuschagne, A.; Louw, A.; Ndanga, L.Z.B. Consumer-Orientated Study of the South African Beef Value Chain. In Proceedings of the Joint 3rd African Association of Agricultural Economists (AAAE) and 48th Agricultural Economists Association of South Africa (AEASA) Conference, Cape Town, South Africa, 19-23 September 2010.

47. Barros, G.S.; Meneses, J.N.C.; Silva, J.A. Representaçóes socaisdo consume de carne em Belo Horizonte [Social representations of meat consumption in the city of Belo Horizonte]. Physis 2012, 22, 365-383. [CrossRef]

48. Food and Agriculture Organization (FAO). Guidance on Hygiene and Safety in the Food Retail Sector. Available online: http:/ / www.fao.org/3/a-i3986e.pdf (accessed on 24 May 2016).

49. Warriss, P.D. Meat Science: An Introductory Text, 2nd ed.; CAB International; Cambridge University Press: Cambridge, UK, 2010; pp. 77-84.

50. Ruban, S.W.; Fairoze, N. Effect of processing conditions on microbiological quality of market poultry meats in Bangalore, India. J. Anim. Vet. Adv. 2011, 10, 188-191.

(C) 2017 by the authors. Licensee MDPI, Basel, Switzerland. This article is an open access article distributed under the terms and conditions of the Creative Commons Attribution (CC BY) license (http:/ / creativecommons.org/licenses/by/4.0/). 